\title{
SOCIAL FUNCTIONS OF COMMUNICATION ABOUT WORKS OF ART *
}

\author{
WALTHER KINDT
}

\begin{abstract}
This paper is hased on the theoretical considerations set forth in Kindt 1981 It provides an introductory survey of the research being carried out in my project "Normal forms of communication about art" In this project, conversations ahout works of art (including literature) are analyzed by means of discourse analysis procedures We have established. on the one hand. that this type of conversation proceeds according to certain socially stereotyped patterns On the other hand the introduction of new approaches to empirical research about art as a soctal phenomenon has become possible These approaches involve, for example. the determination of the functions of art and of communication about art and the characterization of contradictions in the current ideologies of art
\end{abstract}

\section{Introductory remarks}

The decision to abandon the paradigm of traditional literary studies and to treat literature in the domain of empirical social science instead, no longer requires any further theoretical justification. However, such empirical literary studies must stıll demonstrate by their results that their theoretical basis is sound and productive. Thus, in my opinion, it is most important to demonstrate that those problems which traditional literary scholarship regards as central can also be dealt with empirically and more successfully than was possible within the traditional framework One such problem ared would be. for examrie, the topic of fictionality treated in this volume, and more generally the whole field of literary semantics. It is not, however, advisable in such an undertaking to jump headfirst into empirical investigations without previously having considered thoroughly and critically what currently avallable empirical procedures are best suited to the task of dealing with particular questions. Such critical considerations make it apparent that for just these problems in the field of literary sernantics hardly any usable empincal procedures exist For 'xam-

\footnotetext{
- I want to express my thanks to Marilyn Schapıro and Friz Neubauer for translatıng thıs paper into English

This projer 1 was financially supported by the University of Bielefeld (O Z 2366)

Author'c address W Kindt. Uriversitat Bielcfeld. Fakultat fur Linguistih und Literaturwis. senschaf:. Postfach 8640.4800 Bielefeld. West Germany
}

0304-422X/82/0000-0000/\$02.75 1982 North-Holland 
ple. the method of asking direct questions about the understanding of a literary text remains questionable because receivers have only an insufficient awareness of their own interpretation procedures (cf. Kindt 1980) and because there may be enormesus discrepancies between their everyday theories of understanding and their corresponding everyday practice. In the search for appropriate empirical procedures with which the meaning-constitutive activities of receivers could be determined. I became aware. for reasons which I will not go into here. of the posstbilities for employing the theoretical concepts and methods of conversational analysis. The basic semantic postulates of conversational analysis atsume that meanings are constituted only within the process of communication and in the case of face-to-face communication participants construct partially new meanings from conventional meanıng elements in the process of a joint negotiating interaction To the extent that the steps in this construction process are explicitly carried out by the participants in the communication. they are empirically dscertainable and thus an approach to the investigation of meanings 1 , made possible. With respect to the field of hiterature or of art in general. this means that from the analysis of conversations about works of art we can hope to obtain data about the related processes of meaning constıtution These considerations led me to carry out a project in which communicainon about works of art could be dealt with in a more general way in terms of conversational analysis This paper is a report on my work in progress on this project

\section{Goals and procedures in the project}

Social science-based research into the phenomenon of art should not only take as its appropriate subject area the set of those objects which are accepted as art works by socicty: it is much more necessary and useful to choose for the subject area the set of all those interaction processes which bear a direct relationship to these art objects (for such a treatment of Kindt and Schmidt 1979) This means, in particular, that in addition to the communication act realized by means of a work of at. we must also investıgate the communication processes in which the given art objects are spoken about.

In addition to the possibility set forth above of obtainıng empirical access to the processes of meaning constitution by means of the analyses of commusication about works of art, there is a further special motivation for the investiga uon of this communication. It is of great interest to study in more empirical detail the social requirements which are the basis for the production and reception of art, or, in more general terins, the social functions of art. The answers that previous researchers have given to this question have either been only hypotheical or partially even normative in character without substantiating the postulated functions as factual realities (cf. Kindt and Schmidt 1979). 
Aiternatively, inquiries about the function of art are based on direct questioning and these results must be regarded sceptically for the following reasons

- the questionees apparently frequently reprodu.e only those stereotypes about the (supposed) functions of art that they have acquired through their socialization,

- functions regarded as socially negative are seldcm or never mentioned.

- the participants are often not consciously aware of the actual functions art has in particular situations.

In connection with this research into the functional aspect. I start from the assumption that the analysis of conversation about art can yield important new insights. This assumption gains plausibility from the fact tivat the methods of conversational analysis have been successfully applied to the "unctional analysis of niany different types of communication. The investigation of the function quistion has, at the same time, a certain priority over restarch into the specifics of literary or aesthetic meaning constitution. This arises from the fact that interpretation processes are predominantly context-dependent and therefore, in each case, the basic context conditions must be studied n detail before the empirical investigation of these processes can begin $G$ osing beyond this general insight, it has become clear in investigations of problems of understanding (cf Kallmeyer and Kindt 1979, Kindt 1980) that the results of interpretation are dependent to a large extent on certain 1'iteractionally defined prerequisites for understanding which may have varyırg degrees of power It should be apparent that these prerequisites for underst anding in the case of the interpretation of works of art are to a large extent Jetermined by precisely what function the interaction with these works of art has.

The first concern of this project is to accumulate as wide a selection of data as possible. This is accomplished by makıng a large number of tape recordings in the field where, on the one hand, the various branches of art (literature. theater, film, music, fine art) and, on the othe: hand, as many various discourse preconditions as possible are represented. In particular, recordings are being made of experts' and laymen's conversations as well as conversatıons of mixed type. In this connection the problem arises that recordings of experts conversations about art from public prisentations and radio or TV programs are much easier to come by than everyday conversations, that conversation situations occurring on location at artistic events frequently produce very bad recordings (e.g. theater intermissions, gallery openings etc.).

The tape recordings acquired in the course of the project are transcribed in extract form. The transcription system used fulfils, on one hand, the requirement that a "normal" reading of the text remains possible, but, on the other hand, it contains symbols for such phenomena as intonation, hesitation and overlapping which may be relevant to the interpretation The consequent 
analysı makes use of certain conversational andyss procedures which were effectively used by, e.g, Kallmeyer 1977.

\section{Provisional results}

The lask of analyzing the transcribed conversations in this project is still in an early stage. Thus the results of our analysts so far must be regarded as provisional At the same tume, however. the results show several interesting tendencies which I would like sketch out in this article. I intend to consider the following aspects

- peculiarities of interpretation behavior:

- art theory positions:

form of presentation of art descriptions/evaluations.

In addition to these aspects, in section 4 the complex of questions concerning self-definition and self-presentation will be treated separately.

\section{1}

Contrary to original expectations, the analysis of the material so far has yielded little of value for the areas of aesthetic or literary semantics The reason for this is partially the type of conversations recorded so far in which a discussion of concrete interpretations is not in the foreground. bu: rather the conversation partners are concerned only with describing an overall understanding One musi, nowever generally, expect - and this corrects my previous assumption - that such conversations in which particular meaning constructions are explicitly introduced and discussed are relatively infrequent In addition. the expectation based on postulates of current aesthetic theory that the supposed special nature of art would be immediately noticeable in interpretative interaction with works of art must be modified. Apart from the more professional contexts, interpretation behavior turns out to be very "normal". the suggested interpretations are in no way "extraordinary" in comparison with other communication contexts, and. for example, the fictionality of works of art plays no specially noticeable role. The observation of this normality leads me to the conclusion that the frequently expressed postulate about the unıqueness of interpretatıve behavior with respect to works of art even by non-professional communication participants must be based more on ideological grounds than on actual participant behavior. (NB: There may be other leveis where a more marked specificity and distunctiveness of participant behavior may be observed.) $M y$ earlier critique of aesthetic convention and the polyvalence convention (KIndt 1981 ) used by Schmidt (1980) as a central point 
in his characterization of the literary system in society also points in this direction.

The position just formulated emphasizes more generally the assessment that one must not confuse art theory positions with the real empirically determinable given conditions of the processing practice. How gieat the danger of such a confusion is has also been shown in conversational-analytic investigations in other areas of communication: communication practice and everyday theory about this practice diverge widely from each other, for example, in some areas of education The reasons for such differentiation between theory and practice lie primarily on two levels:

(1) The practice is frequently not sufficiently cognitively understood by the communication participants, thas $1 t$ cannot be adequately described by them. However, a precise cognitive grasp and a verbal description are not required for a successful practice and are thus not expected by society

(2) Theoretical positions are established by society partially for purposes of legitimation Contradictions between theory and practice thus occur of which the partıcipants are .'so partially aware. Insofar that the ve theoretıcal positions in spite of such contradictions appear to be socially iecessary. the contradictions are "resolved" with the help of certain socially stereotyped strategies One can purposely overlook the contradictions or deny them, or present them a, unavoidaiole or declare them as sacred and inviolable.

To elaborate this differentiation between theory and practice let us consider the example of fictionality: the stress on the fictional aspect of hterature evidently had the purpose, historically speaking. of protecting $v$ riters against certain claims made by society on their work and to limit their :esponsibility for their utterances and especially for the interpretations of them by others This stress on the fictional aspect does not mean, however, that fictionality in literature plays a greater role in practice than in other areas of communication. In my opinion, fictionality is a phenomenon which plays a very large role in such fields as playing and learning and thus is not a distinguishing feature of itterary systems (cf. Kindt 1981).

The empirical investigation of actual communication behavior $w_{1 t h}$ respect to fictionality as well as the acquisition of the corresponding behavior conventions through socialization is discussed by other authors in this volume. In keeping with my argumentation above, the differentiation between theory and practice should be given particular attention in such studies. Thus. although Hurrelmann's work (1981) suggests that prımary school children are capable of making considerably sharper thecretical differentiations with respect to the fictional aspect of literature than assumed by Schmidt (1980), this tells us nothing about the effect of fictionality on actual participant behavior. Accord- 
Ing to my observations, the question spontaneously asked by children of kindergarten age in the act of communication relates only to the distinction between real or not real (in German colloqual language today that would be. ist das in cifi so? ("is that really so?") Furthermore, in my opınion, we must demand of empirical investigation that it reflects explicitly that aspect of the function of fic:tonality relevant for the given interaction context. Only by taking into account this aspect is 11 possible to answer questions about the effects on the micro-level of interpretation processes.

\section{2}

On the level of theoretical discussions about art there are several frequently recurring controversial topics. Included here are. for example, the requirement that art be comprehensible or the question of the function of art. Such discussions are well known to us all, thus it seems in mentioning their frequency that nothing new is being sand. If. however. we compare a large number of such discussions, then their similarity or stereotypicalness becomes apparent. This stereotypicalness is in striking contradiction to the fact that such discussions are experienced by the participants as spontaneous and also defined as such by both sides. We can surmise about this kind of conirast that the discussions in question actually proceed according to socially regulated and acquired patterns of which the participants themselves are not aware. Such an assumption is based on similar experiences in different interaction contexts. Thus the question arises as to which social functions are involved such that participants express certain art theory positions in these discussions and, at the same time, are not completely aware of the background of these positions.

The complex of problems arising from the preceding question will be made concrete here through the example of the comprehensibility requirement. On the question of the comprehensibility of art various contradictory positions have been advanced. On one hand ts the requirement that art should be equally comprehensible to everyone; such as is expressed in the statement of an officiai of the German Federal Ralways:

Aber ich liebe Kunst in allen itsen Ausdrucksformen ah asthetischen Ausdrucksformen des Schopfungswillens des Menschen eben So war er durch durch Jahrtausende hin fur alle Menschen verstandlich, und ich kritısiere heute an der Kunst, dass sıe oft fur den eben nicht gebildeten Menschen ah kunstgebıldeten Menschen so unverstandlich ist (Radio program from the WDR on $11 / 10 / 1979$ )

[But I love art in all its forms uh aesthetic forms of expression of the c:eative desire of man That's why it has heen understandable to all men for thousands of years and what I cnitictze today is that art is often so incomprehens'ble for uneducated uh people, uneducated in art ]

On the other hand there are positions which claim that art can never be comprehensible; such as expressed in this version of the approxımative com- 
ment made by a publisher of experımental literature: $I$ have never published anything that I have understood (1978) In between there are positions which give varying weight to which prerequisites one must fulfill for the comprihension of art and which expectations are appropriate to these prerequisites As contrasting examples I want to quote here $t$ le statements of the author Max Bense (1971) and those of a student of Gerinan literature (1981). Max Bense stresses the elitism of art:

Wer Kunst verstehen will, der muss genauso viel lernen wie derjenige, der ein Auto konstruiert I ] Wer nicht begrifien hat, dass Kunst elitar ist, der soll die Finger davon lassen I I Kunst ist e'ne schwierıge Angelegenheit. genau wie Mathematık Man muss es gelernt haben (Cf RichterReichenbach 1977 126. 129, 141)

[Whoever wants to understand art, must learn just as much as he who uants to construct an automobile [ ] Whoever has not understood that art is elusst should keep his fangers off it | Art is a difficult pursuit. just as mathematics One has to have studied it ]

The student Tilmann expects in contrast that the necessary information for the comprehension of art should be accessible to him without undue hardships

Ja. das schreckt mich zum Beispiel ab mal in die Kunsthalle irgenduo hinzugehen. weil uh man manche Bılder oder manche Farbkompositionen oder "gendetwas nicht erfassen kann well das ja eben was nicht Geuohntes ist

[Yes, it deters me. for example, to go sometimes into a museum somewhere because I you car't grasp some pictures or color composttions or some things because it's something you dre not used to ]

To the response of his fellow student Richard

Ja. dann musse dir nen Beglestfuhrer kaufen fur dretssig Mark oder was we ss ich duch immer

[Well then, you have to buy yourself a guide book for thirty marks (ir something ]

Tilmann replies with reference to such a high price

Ja, weil fur mich das auch nicht leistbar ist, ne

[Yes, but l just can't afford that. right?]

For such positions there are simiarly typical explanutions. As in the above quoted statement of the railway official, for example it is clamed that art in earlier periods was always compretensible. Or the requitemen. for the comprehensibility of art or the introduction of an intermediary for making comprehension possible is justified by the fact that otherwise the social responsibility o. art would not be capable of being fulfilled. Numerous ciemands for the 
comprehensibility of art also drise in relation to the price of acquiring art objects. Thus, for example (in 1978), a twenty-nine year old turner expressed the following opinion about certain street sculptures purchased by the city of Hanover

I J denn alleen uas die Soxkel gekostet haben. es ist sagenhaft I | Man kann mit dem Geld atuh ein bisschen mehr machen, was mehr Leute anspricht. denn diese Skulpturen sprechen doch nur wenige $\mathrm{I}$ eute an (Cf Heine and Wevemuller 1978 162, 165)

II I what the pedestal alone cost o fantastic I lOne could redly do more with this money that would reath more perple, because these sculptures mean something onlv to a few people ]

\section{A twenty-four year old locksmith and plumber critıcizes:}

Ih wurde sagen. da hat de Stadt stel Geld rausgexhmisen. da haben ste eir. paar Figuren hingestelft wo sh 'n Arbeiter kaum etuas dranter vorstellen kann Das sand alles Personen ohne Kopf, wohl die gleichen Leute die dise Dinger gekauft haben (Heine and Wevemuller 1978 162)

If would sat the cit, has throun audy a lot of money, they have stukk a couple of statues there whik no workıng man can make anv senve out of These are all people withou hedds. probably just like those people who bought these things!

From another point of view the attempt to make art comprehensible is regarded as doomed from the start.

Neın. das liegt an den Volksschichten. die sind zu dumm dafur' Gehen Ste doch mal von hier bis zum Bahnhof und suchen Sie jemanden, der dreı Takte von Schubert oder dret Takte von Stckkhausen begrelft (M Bense of Richter-Reichenbach 197; 126)

INo, the fault hes with the class of people. they are too stupid for II' Take a walk from here to the rathay station and look for someone who understands three notes of Schubert or three notes of Stixkhausen ]

Sagen uir mai $90 \%$ konnen velleicht nichts damu anfangen mit Kunst Die konnen mit Beethov:n auch nichis anfangen, die konnen uberhaupt mit keıner Kunst etwas anfangen. auch mit der Kunst. von der sie glauben. dass ste ste kennen und die ste mit funf Mark auf der Schaliplatte kaufen konnen ( J Und es hat auch keinen Sinn. finde tch. wenn man - wie das nit Vorstellungen "Kunst furs Volk" versucht wurde - jetz" diese Kunstformen mit Brachalgewalt gewissermassen, den $90 \%$ einzuhámmern, was man ja in einer Diktatur machen konnte. [ J Aber sie uurden dann noch lange keın Verstandnis dafur entwickeln, weil ste das nicht brauchen, nicht so notwendig brauchen wie andere Dinge (F Kriwet, of Richter-Reichenbach 1977 184-185)

[Let's say that $90 \%$ probably can't even begin to deal with art They can't deal with Beethoven. they can't deal at all with any art. even with that art which they believe that they know and that they can buy for five marks on a record I J And it also makes no sense. I think. for anyone now to try with brute force to hainmer into these $90 \%$ these forms of art - that's what has been tried with the performances of "Art for the People". that's what you can do in a dictatorship | | But they sull won't devell $p$ any understanding for $1 t$ because they don't need it, or they don't need it as much as they need other things ! 
It is also often argued that art was never comprehensible to its contemporaries:

Einen Zahn mochte ich Ihnen eigenthch ziehen von vornherein und d wat, dass die Kunv in den le'zten Jahrtausenden immer verstandlıch war Fur die Zeitgenosien stımmt das nichi Also wenn wir uns nur mal hundert Jahre zuruckbewegen die Impressonisten | I This was the answer of an expert in the above mentioned WDR program)

[One thing has to be cleared up from the beginning and that w that art wa aluas comprehensible over thousands of years This in simply not true for the contemporartes If we go back. for example. a hundreis years to the impressionists [ 1]

Other fcrms of argument attempt to point out the negative consequences that would result from the realization of the comprehensibility requirement for art.

You can see in the suclalist countries where the comprehensibilitv requirement gets you' (Approximate statement of an author of concrete poetry, 1979)

Sonst ware Kunst einfach ein Darsteilen von ırgendwas Redem, uo Du dann sagen unmutelbar was mit anfangen kannst. weil Du siehst da eben 'nen Hasen oder so was Ich meine das ist nicht mehr der Sinn der Kunst, ne, man daruber ist man uabrscheinlich hinaus jetzt (Sad bv the student Rıchard)

[Otherwise art would simply be a representation of something real, something where you could immediately say what it means to you because you see a rabbit there or some such thing I me an then it's no longer the purpose of art, it's just going too far $]$

In connection with discussions about the comprehensibility and communicativity of art. certain contradictions and specific reactions become clear. As, for example, the student Richard recommends to his colleague that he should lower his expectations for comprehension

Ja kann man sich denn nicht nur einfach daran erfreuen Oder Du hannst auch einfach spontan sagen das Bıld gefallt mir oder es gefallt mır nıcht

[Well. can't you just simply enjoy it Or you can also say spuntaneously "l like this picture" or "I don't like it"]

On the other hand Ruchard rejects the idea of responding to art without any presuppositions.

I I kannst Du die Kunst nicht so schnell konsumieren. Du ka'ılst nicht so durch ne ne moderne Kunstausstellung durchlaufen und danach gehen. gefallt mirs, zefallt mirs ntcht, stell wh mich da zehn Minuten vor und lass das wirken oder nicht

II ] you can't just consume art so quickly. you can't just run tl ough a modern art exhibition and then leave saying "I like it" or "I don't like it" - I stand in fisint of i. for ten minutes and let $1 t$ work or not ] 
The contradictions expressed by Richard between social aspırations for participation in art and comprehension difficulties are typically resolved by professional representatives of artistic institutions by denying one of two contradictory elements A. M. Beise expresses it:

Wu mus doch nocht jeder Backer, muss doch nuht seinen Plcasso in seanem Schlafammer hangen haben, wie se fruher Raffael hangen hatten' Ist doxh nicht notig' (C) Richter-Rekhenbach 1977 129)

It vers baker doesn't have to have hu Pacaso hanging in his bedroom as he prevosusly would have had his Rafald It' not necessary']

In contrast. the artist Josef Beuys assumes that where the author does not want to give any interpretation for his work of art. then the recipient also does not need any help. Der wird aber damu fertig (Richter-Reichenbach 1977 · 167) ["He manages nevertheless"]

Further contradictions result from the separation of art production from the later process of reception. The artıst Heinz Mack stated the basic problem in this widy.

V.eflenht as en Widerspruch daran dass der Kunstler zunachs fur ach allein arbeitet grosstmiglthe Egozentrik - und dass er anderersets die Geselluchaft braucht Oder. Juch erwartet. dass die Gesellschaft seine Arbeit nicht nur tolertert. sondern auch irgendirte gouttert. das de Gevelluchaft also duch won diever Arbeit profituert, im tdeellen Sinne (Ruchter-Reichenbach 1977207 )

PPerhap, there is a contradiction in the fact that the artist works first for himself alone - most probably egocentrically - and that. on the other hand. he needs society Or he also expects that wolets not onl tolerates his work but also somehou appreciates it and that the society also profits from the work in the ideal sense]

Here, in contrast to the previously mentioned contradiction, the perspective of art production is dealt with. A typical reaction to this is that the artist prodi is only for himself and not for recipients. Marc Adrian, for example. expresses it like this.

Ich halic den Rezipienten fur eine relatıv sekundare Instanz som Standpunkt des Produzenten aus (Cf Schamadi 1979 215)

[1 regard the recipient as a relatwely secondary factor from the standpoint of producer ]

And a Bielefeld author responds (1981):

Man schreıbt ımmer zunáchst fur sich Ob dann der Leser oder der Burger das aufnummt oder nicht, das ist seine Sache

[One aluays writes first for oneself If, then, the reader or the citizen takes it up or not, that's his business ] 
Even more interesting than the various positions with respect to these contradictions are the strategies that are used to support or protect these particular positions. First of all, there is the strategy common in other areas of assertung the authority of one's own position or making the opposing position appear ridiculous: the recipient who claims that participation in art is a possibility makes fun of those works of art which remain incomprehensible to him. the recipient or producer who rejects the social function of art presents his position dogmatically as the only possible one etc. M. Bense, for example. uses this strategy in an extreme form (cf Richter-Reichenbach 1977: 125-134) In addition, however, there are also strategies within the framework of which participants - in many cases without being aware of it - exhibit contradictory behavior. Recipients who reject the demand for general comprehensibility in art can often not admit to themselves, because of their self-confessed postion as art experts, that they do not understand partucular works of art in this case they attempt to hide their lack of understanding and may pretend to play the role of enthusiasts. Or, artists, on one hand. claim that they produce art only for themselves and that they bear no responsibility for the effect of their products on recipients, and then, nevertheless, on the other hand. frequently firt with public success and attribute it. when it occurs to themselves or are disappointed when it does not occur. The above mentioned Bielefeld author (1981) has found a formula that allows the attribuiton of success to the artist irrespective of the variously postulated types of reception in the following words.

Und trotzdem ist es immer dasselbe Werk. das immer wieder neu dufgenommen wird $\mathrm{d} h$ es ging durch alle Verwandlungen hindurch, bewahrt es sich und bleibt trgendetuds Wesentliches ah an dem die Menschen sich in irgendeiner Weise auch orientieren, aber wie. das ist dem Autor entzogen

I Ar 1 nevertheless it is alwavs the same work that w over and over agatn new It percerved that is it zoes through all the transformations preserving atself and something someh,u essential reman, uh. around which peore in some way orient themselves, but the way this happens is independent of the author]

As a response to disappointed expectations for success and understanding artists have developed a strategy of "Verarschung" [hardening themselves] which is well-known to both producers and recipients of art. the uncomprehending recipient must be made a fool of untıl he finally wakes up and grasps the message of the artist.

If we consider the above mentioned positions and behavior patterns as problems in the comprehension of art. then it is more important to inquire about social functions than to seek justifications for these positions and behavior patterns. In order to deal with this question it is certanly not sufficient to analyze the discussions about the comprehensibility problem 
themselves, yet. at the same time, one must be careful not to engage in one-dimensional evaluations of functions Thus I do not want to speculate too far about function postulates But on the basis of the material avalable to me. there remains no doubt that. for example. the postion of rejecting a comprehen sibilty requirement for art is a powerful instrument for setting up social boundaries. This instrument may be used by an artist in order to protect his products from too rapid consumption, but certainly it of ten serves artists and recipıents in estabiıshing their social identity (Individuality, geniality, membership in an elite. etc) On the other hand. if an artist insists that art fulfil a soctal function and that it be comprehensible, this should not be regarded only from the perspective that in this way he is fighting for equal opportunity or showing concern for the needs of the people. for an artist the function of legitımuzing his political or commercial interests can also be at stake and for a recipient posssbly the function of unconscious self-stigmatizing or implicit self-exclusion from the group of participants in art may be involved. In dddition to the investigation of the function question an explanation must also he found as to why the above mentioned contradictions remair unnoticed or partially hidden. With respect to the answering of this question, $i$ assume that on one hand. many of the functional contexts of the art industry are generally not consciously perceived by participants, and. on the other hand. phenomena such as the implicit formation of elites are not perceived by certain participants because they are not compatible with their ordinary theoretical value judgments A sufficiently precise answer to this question requires still more thorough research efforts

\section{3}

According to my impression so far. patterns of behavior with respect to art are far more socially stereotyped than is generally assumed. In the field of pictorial art this stereotyping hegins as soon as the art object is approached and is visible in the participants body language while they are considering it $\mathrm{My}$ man interest in this resedrch concerns the search for patterns in written and oral communication about art and the analysis of the associated forms of cooperation Here I will only give a brief survey of some results bearing on this question. In many contexts in which communication about art takes place. part of the god in the interaction consists of evaluating a particular work of art and. possibly, firsi describing it. This task is obviously accomplished with the help of a socially standardized communication pattern; this pattern consists of certain obligatory or optıonal components which must be dealt with in a more or less exactly established sequence. The overall structure of this pattern follows this outlıne the first step is a prelımınary evaluation. then comes a (brief) description. after that. Individual aspects taken from a standard repertory are judged. and finally a composite total evaluation is made This 
structure is, for example, approximated in the following two conversation extracts (here the notation ( .. ) is used for an incomprehensible phrase).

$S$ Aber was th unhemich dufte fand, da war ean son Bild ( das war daese nackte F rau aber das war so son ganz grosses, und das sh aus, als wars n Foto, gane verschuommen aber das war auc' gemalt (, Also das fand ich unheimlich tolf wie das gemalt (, Das hıng da, wo da warn alles so Schreibmaschinen gemalt (, Und das fand ich gans toil

(What I thought was really super $u$ as that there was this picture (), there was this naked woman but it was really big and it looked like it was a photo very hlursy, but if ua alot painted( ) So that's what I thought was really fantaste hou 11 kas panted ( It was hanging there, and everywhere there were typeurters panted, , And 1 thought that wa really fantastic ]

WI Wahrend Sie ja etwa so gute Sachen wies neukich gegeben haben soll $(1$ diesen dewen polnischen Film nach Josef Conrad diesen Wajda. ah Sehattenhlie. das hat am ZDF gegeben das soll ja glanzend gewesen sein

W2 Mhm

W/ Von diesem Andrzej Wajda

$M$ Hams nicht gesehen

WI Die Jugendentwicklung eines jungen Kapitans der dann plotzich die Verantuortung in schweriger Situation fur ein ein Segelschiff der Jonef Conrad a jat der leadenuchaftliche ath Seefahrer gewesen Und das is der konnte chon schrethen das is fat auch son Mann der um de Zeit geschrieben hat. als d $\mathrm{r}$ als der Gakworthy gelebe hat Ja du hannst naturlach sagen Peter, das is alles irgend o almodisch aber es is f und mir machis halt Spas

[W] When there are uch good things on as they were supposed to have the wher night ( ) this this Polish filn based on Josef Conrad. this Wajda uh The Shadow. Lime that uas on the second TV pri gram. It was supposed to have been outstanding

W/2 Uh-huh

WI By this Andr, Wajdd

$M$ We didn't set $\mathrm{It}$

W/ The adolescesit development of a young captain who then suddenly in a difficult stuation is responsible for a sailing ship so Joseph Conrad was a pasionate uh sulor And he was he really knew how to write and he was a man who wrote about the tume the. Galsworthv !red Yeah. Peter, you can, of course, sdy, that it's all sort c fold-fashoned but it s, 1 realls enjoy 11 ]

In both examples the central part of the outline, the judgment of individual aspects. shows up only in fragmentary form In the first example only the technical quality (painted, looks like a photo) is mentioned and this is an aspect that is often referred to as a basis for judgment In the second example. the aspect of the biography of the author and the aspect of the period in $u$ hich it was produced are mentioned

Other frequently used judgment processes are. for example. the possibility of finding a meaning, the decision as to whether the artist is a professional or an amateur, or whether he is traıned or self-taught and determınıng the price of the work of art.

Heine and Wesemuller (1978) have already noticed that the choce of which 
aspects to judge depends, anong other things, on what kind of access the evaluator has to the work of art as well as to what extent he regards himself as an expert. A judgment from the perspective of a blue-collar worker is illustrated in the following utterance made by a 33 year old plumber (P) and by the above quoted locksmith (L) and plumber concernitig some street sculptures in the city of Hanover:

$P$ Denn diese rotierenden Walzen - doch. wurde ah sagen - getatit mir Gefallt nur, wesl man da aus diesem Ding die Techinık hekommt Ich bin ja gelernter Maschinenschissser und da mus man ahnliche Prazssonsarbeit liefern Also mis gefalts, es ist alwo ataht argendetwas hingestelit

I Den Brunnen hier | I der gefallt mir materialmassig - Bronze uahrscheinlich - und die gande Arbeit. ich bin gelernter Buschlosser und da gehort auch Kunstachiossere dazu | J. die Arheit, diese Blatler, das finde ich wunderbar' (Cf Heine and Wesemuller 1978 175, 177)

IP Becaluse these rolating chlinders - ves. I would as I lake them I like them betause from this thing vou get wme sense of technology 1 am a trarred machimist myself and there you also need to do that and of precision work So I like it. it' not just throun together

I The fountain here I I. I like that in termy of the material - probably bionze - the whole work. 1 am a trained locksmuth and artuste metal work is also involved in that | |. the work here thewe leaves, I think they're nonderful']

The inclusion of autobiographical aspects, especially interest in foreign travel, in particular the experiences resulting from it. is, for example, clearly expressed in the statement of a 34 year old locksmith

Jd das werglenchbar mut Brussel. dies Atomium Man konnte vielleicht in fernen Landern so'ne Art velleicht als Schopfwerk. so altmodısche Schopfrader. konnte man das vielleicht bezeichnen (Heine and Wesemulter 1978 176)

[Yes it' comparable with Brussels, the Alomium In foreign countries you could probably call comething like that a bucket elevator, a kind of old-fashioned water wheel]

This extensive detailing of particular aspects for judgment and the demonstration of expertise can, on one hand, be explained by the fact that the communication participant frequently try to make maximum use of the communicative wavelength available to them. On the other hand, it seems to me that we have to see here more generally, a connection between communication about art and the aims of self-presentation. I will discuss this point in more detail in the next section.

Evaluations of works of art are not merely expressed but also, possibly, reasons are given, as well as emotional support. In providing a foundation for these evaluations social standards obvtously come into play as well In the above quoted statements we have already seen that the evaluator presents hımself as an expert in judging a particular aspect and in this way "strengthens" his judgment. In addıtion. or instead, other authoritıes are frequently cited. For 
example, the above mentioned Bielefeld author (1981) expressed hımself in connection with the discussion about the possibility of an objective evaluation of poetry:

Nun ja. wir haben ja selbst festgestellt, dass ein. Kommerell z B ene ( ) gute Sachen dazu ge-agt hat, hat 2 B gesagt, bei einem Gedicht kommt es auf den Zustand der Sprache an. und das isl has sehr Wichtiges

[Now, we have already established that. say. Kommerell for example () has made a g od comment on that, he has. for example, said that with a poem it's a question of the condition of the language, and that's something very important )

Another, frequently used argument is when one clams that a large number of other communication participants share one's own opinion As an example, the above conversation extract from $\mathrm{W} 1, \mathrm{~W} 2$ and $\mathrm{M}$ is preceded by a passage in which W1 pronounces a judgment on the Forsythe Saga

Als ich in der Prima war, da war das das Modernste von England uas man so haben konnte Ich hab das auf Englısch die ganze Forsı the -Saga gelesen, war so begerstert und und meine Mutter las das auch und Sybille las das Das fand man eben grossartig

[When I was in my findl year in school, that was the most modern thing from England that you could have I read the whole Forsyzhe-Saga in Englısh and I was so enthusidstic, and my mothe' read $1 t 100$ and Sybille also One thought it was great !

In evaluations, emotional support plays a special role Here there is a range of stereotypical expressions. In face-to-face communication they are to a large extent on the level of body language and intonation, in written communication there are, in contrast, only stylistic means such as word chesce and text structure which are avalable. The stereciypicalness of such means of expression becomes especially clear when thi; are overused and when the resultung statements become almost caricatures In this respect the art revieus in the provincial press frequently have an amusing effect, consider as evidence the following text extract (Neue Westfalische)

Die Spannung in der Oetker-Halle am Samstag war gross Eine 15-jahrige Geıgerın aus Herford wurde das vertrackte und anspruchsvolle Violınkonzert von Johannes Brahms spıelen? An kopfschuttelnden Zweiflern hatte denn duch nicht gefehit - es sel aber gleich gesagt Viola Sommer brachte ste zum Schweigen Hochgeuachsen, mit langen dunklen Hadren grossen braunen, angesıchts des ausverkauften Saales etwas erstaunt blickenden Augen im aparten, hlaren Gesicht. so betrat sie mit dem Dirigenten Wolfang Drees das Podium [ ] Mit bew undernsuerter technischer wie nervlicher Sicherheit ging ste den schwierigen Solopart des Brahms-Konzerts an. dem kosibaren Instrument (eine Bergonzi des Jahres 1723) entlockte sie mit vorbildlicher, ja duch asthetısch schoner Hand- und Korperhaltung einen schlanken und gleshermassen vollen, sussen samtenen Ton, dem es indes auch nicht an zupackender Kraft mangelte Der Klarhett und Reinheit threr personlichen Ausstrahlung entsprach so ganz thr Geigenspiel und die Interpretation des Konzerts, diese Eınheit von Physis und Geist war es denn auch, die die Spannung der begeisterten 
Zuhorer schliesslich in Ovationen entlud | | Der Orchesterklang blicb dennoxh stets klar und hell. die dvnamischen Schattierungen beusesen die growen Differenzierungsmoglichkeiten des jugendlichen Orchesters (die uber 80 Mitglieder stehen im Alter zwischen 13 und 24 Jahren) Wolfang Drees feuerte es mit Elan und wetten Gesten an. holte den melodischen Fluss in den Instiumentalgruppen plastisch hervor animierte das Orchester, das ich als einheitluher Klanghorper bewtes zu schmeichelnden Pianıssmo- wie auch schmellernden Fortıssimo-Klangen Dvorak sanfi und zart wie eine elegische Klage und heftig wie ein Wirhelstrum uber der Prarie l 1

The teision in the Oetker Hall on Saturdas night was tremendious Was a 15 vear old volinist from Herford going to play the intricate and demanding volin concerto of Johannes Brahms" There were plents of head-shaking doubters - but let it be and immediulely that Viola Sommer brought them to a hushed vlence The tall girl with long. dark hat and large brown eves which eened astonshed in facing the fully sold-out auditorium and with a charming clear face. came on to the perdium with the conductor Wolfgang Drees I | With admurable technical aktl and componute she hegan the difficult wlo part of the Brahms concerto She elacited from the valuable instrument (a Bergonzi of the vedr 1723) nith exemplary even desthetkally bedutiful hand and hodv motements a fine. at the same tume full, sweet velvet tone which also centained great strength The tharitv and purity of her personal radiance fully corresponded to her volin playing and her interpretation of the concerto this unit of body and spirt was what finally defused the tension of the enthusastic dudience in a standing ovation | I The tone of the o,chestra remaned alu ats cleat and bright, the dinamic shading wa proof of the great differentiating ability of the voung orchestra (the more than 80 member are between the ages of 13 and 24) Wolfgang Drees inspired the:n with elan and broad gevtures and drew from the instrumental groups a melodic flou he anmated the orchestra which plaved da a single unit from sof pianissmo to blasting fortissimo Dworak soft and tender as an elegiac lament and sudden as a tornado on the prairie I I]

In judging such examples as this, we should bear in mind that, to a large extent, it depends on the emotional state of the communication participant. whether he regards the choice of a particular emotional means of expression as overdone or not. At the same time, the use of such expressions is not, of course, limited to communication about art, rather it is common in the context of all value judgments. We can also not exclude from this category the field of academic discussion which by outsiders is frequently regarded as the prototypical case for the dominance of rationality. Consider the following statement made by an academic about his colleague:

Ich glaube, wir haben in Herri Falke einen Mann und zukunftigen Kollegen. der duf beispielhafte Weise dieses miteinander verbındet. insofern als er die Wissenschaftstradition kennt, dber doch deutlich in seinen Schriften und in seinem Vortrag und in seiner dynamisch und anarchischen Art zu diskutieren deutich zu erkennen gibt. dass er in einem anderen Ambiente zu denken, zu handein und zu schreiben pflegt Dies ist Wissenschaft mit Leidenschaft betrieben, und ich meine wir soltten den angeneiımen Schock, der damit verbunden ist, als eine wesentliche Bereicherung der Denkpalette unseres Instituts ansehen und dankbar sein, dass wir uns nicht einfach mit unseren Denkgewohnheiten, die seit Jahrzehnten eingerastet sind, bet uns regenerieren, sondern dass wir auch andere Denkgewohnheiten und auch anarchische Denkgewohnheiten. also jedenfalls leidenschaftiche Denkformen in diestr. Institut akzeptıeren

II beheve we have in Mr Falke a man and a future colledgue, who combines these features in an exemplary way. to the extent that he is familar with the academic tradition and yet at the same 
ume clearly makes it known in his writıng and in his lecture and in his dynamic and anarchic way of discussing things, that he is used to thinking in. dealing with, and writing in a different milieu This is scholarship with passion, and I think, we should regard the pleasant shock that is connected with it as an essential enrichment of the thoughtpalette of our institute and we should be thankful not simply that we continue to reproduce our habitual patterns of thought which have been established over decades, but rather that we also accept different patterns of thought and anarchic patterns of thought, that is, anyway, passionate thinking patterns in this institute]

Especially noticeable - but equally not typical only for the field of communication about art - are, finally, certain types of cooperation between communs. cation participants in the case of corresponding or differing evaluations. When differing evaluations occur one can observe the introduction of and tolerance for techniques by means of which a subsequent argumentation concerning the differing evaluation position is blocked. One of these technıques consists of the suggestion that, concerning the points of difference, various subjective opınIons are possible. Conversely, when parallel evaluations occur one can observe an extraordinary amount of cooperativeness This can be seen from evaluative completions by the ot ner participant as well as from repeated mutual ratificatons concernıng the cingruity of judgments. And it even may be the case that a successive emotion. . loading up of the evaluation occurs accompanied by euphoria over shared feelıngs (cf. Kallmeyer 1979 and his statements on the interaction modality "exaltation"). This cooperation technique will perhaps become clear in the following conversation between an art dealer (D) and a customer (C) where they are concerned with the evaluation of a picture by an amateur painter and for the fourth time in this conversation increasingly close agreement on the value of the picture is in the foreground.

D Mhm am starksten ist es eigentluch hier, da haben Ste schon recht hier ne so dies ist vielleıch C [ dann micht so, aber sch meine

$D$ Jd Es ist vielleicht sogar, ich meine, es is

C L Mhm

$D$ auch so die ganze Komposition ne. die, aber das is schon sthr schon gematht. also

C

C dusgesprochene Starke der Wald da

ID Mhm it's actually most intenswe here, you are right there. here not. wo this is perhaps not so.

$$
\begin{aligned}
& C \int_{-}^{\text {but I think }} \text { OK, you say with the sky } \\
& D \text { Yes It is perhaps then. I mean. It is also }
\end{aligned}
$$$$
\text { C }[\text { Mhm }
$$

$D$ The whole composition. isn't it. which. but it's certainly very beautifull, done C L

fantasttcally strong this wood here ] 


\section{Self definition and self presentation}

At the literary symposium "Styrian Autumn" in the city of Graz last year (1981) an excited discussion touk place on the topic of "The Writer as Outsider". In this connection Greiner made several remarkable points by which he tried to claim that the writer's sense of being an outsider is to a large extent merely a legend produced in common between the author and society (cf Greiner 1981):

The uriter 1 an outsider. but most of all. It seems to me. he wants to be one He seeks out the sigma of being on the outside in the hope of partaking of the aura of the Chosen [ ] The reality of heing a literars outsider has become sanctified and fortified by legend A strange reversal is a comvequence of this In many cases the author is not regarded as an outsider on the strength of being a writer, but rather he makes himself into an outsider in order to be regarded as a writer And that is why, when the literary public grants him uell-meaning acceptance and praises him with distinction, then his role appears to be endangered Whoever publicly imbraces the writer deprives him of being an outsider The writer resists in so far that he is provoking and he hopes that this provocation will work - and that the public will push him back into being an outsider The public. however, is. as we know, prepared for this provocation and so 11 looses its effect Since they also regard the writer as an outsider, they don't expect anything else

Gremer draws attention to the fact that, in spite of the many unquestioned disadvantages due to bad economic circumstances and partial disiegard by society etc., the role of the writer has so many advantages that one cannot really speak of his being a genuine outsider. the writer receives much more tolerance from society than normal citizens, he possesses a constitutionally guaranteed freedom for his work and he enjoys. like other social groups, the privilege that his work is subsidized with public money. Ther work is not under the usual pressure of having to demonstrate social usefulness and they have chosen this job for themselves. Normally they lead less alienated lives and are more free from material concerns than ordınary employees and finally they enjoy enormous social prestıge. Greiner describes this prestıge as follows

The public who is educated or interested in education still regard it as an honor to sit face-to-face with a writer in the flesh at a poetry reading You can see over and over again that mature houseuves who have a life of hard but not very much appreciated work behind them hold their hooks to be signed with expectant hands. The fact that someone has written a novel or a volume of poetry rases him above the speechless mass of the non-literary and lends hum a special kind of durd Pubic presentations of prizes frequently become solemn occasic ns, where the prize givers borrow some of this dura Why do presidents and ministers attend these occassons if not for the reason that they attribute to writers and their works a very specific prestige value? And when writers protest against the neutron bomb then this protest remains ult mately impoteat but it has. at least. greater public significance than a similar declaration from German pharmacists would have, although the latter are scarcely less competent to judge the matter

If Greıner's theses are correct and, in particular, the value of literature for social prestige is correctlv described. then. in general, we can expect that 
communication about art would frequently be used to claim and establish entitlement to this social prestige. Precisely this function of communication about art has been evident to an astonishing extent in my analysis so far of the material I have gathered. I would like to illustrate this with several passages from a conversation.

The basis for a more precise analysis of these passages is provided by the conversation analysis procedures developed so far. On the other hand, certain insights into self-presentation techniques which I have gathered from other contexts are also relevant to this conversation. In what follows, however, I cannot explicitly introduce these analytic instruments and therefore limit myself to sketching the results of the analysis.

The female student (SW) and the male student (SM) visit the artist (M) in his newly established private gallery in which he displays mainly his own pictures.

$M \quad$ Und hier hat meine Frau funfundzwanzig Jahre lang ein privates Ferienkınderheım SW $L_{\text {Ach }}^{\text {betrieben hat, das hain }}$

$M \quad$ wir zum ersten Mal dies Jahr nicht mehr gemacht

$S \boldsymbol{W}$ - Mhm

SM Is ja doll, das wusst ich auch noch nich

$M \quad$ Und eh so nam wir auch schon im voraus immer inner Planung die ganzen Raumlichkeiten $S M \quad L$

-so konzıpıert, dass man hier also eıne Galerie eh unterhalten kann nich, und th Sie konn

$M \quad$ ja jetzt mal sehn. eh wie ueit

ja

$M$ das gelungen ist, nich nich, unsere so ne Galerie gibt es in der ganzen Stadt nicht wit diese

SW $\left[\begin{array}{r}\text { hier, nich. } \\ \text { Mhm }\end{array}\right.$

$S M$ Eh

$M$ mit den Raumltchkeiten, die sind ja sehr grosszugig. nich. und man hat Platz ja

I $M$ - And here my wife directed a private children's summer camp for tuenty-five years $S W L$

$M \quad$ This year is the first tume she has - we haven't done it any more

SW $\quad$ Mhm

$S M \quad$ That's great. I didn't know that before either

$M \quad$ And so already from the beginning when we were planning it, we concesved the whole

$M \quad$ Space in such a way that we could also put a gallery here. nght. and uh you can see

$S M L$

yes

$M$ now, uh how well it's worked out. right. right our, a gallery like this one can't be found $S W$
$S M$
$M \quad\left[\begin{array}{c}\text { anywhere in the whole city. right, and with the space } \\ \mathrm{Mhm} \\ \text { Uh }\end{array}\right.$

The self-presentation technique used by $M$ in this passage is easy to see through $M$ presents himself first of all indirectiy as a person who has developed his artistic ambitions with a consistent goal over a long period of 
tıme The dream of probably every artıst - of openıng his own gallery - had already been planned by hım and his wife twenty-five years ago and he can now realize $1 t$. With the pessession of his own gallery $M$ has reached the level of the publicly acknowledged and socially stabilızed type of the artıst. But it is not just any gallery he has opened, but. from the point of view of space. it is the most generous gallery in the city. M does not even give SW and SM the chance to answer his question about whether the preconception of the space has actually been worked out in practice, rather he immediately brings his own positive evaluation into the conversation. The self-presentation technique applied here consists of the fact that the positive evaluation of the gallery is attributed to a corresponding positive evaluation of the character of $M$. he is an artist who on account of his gallery can be admired and envied and whose icial prestige in the city is of high estumation. The process of indirect positive self-evaluation through explicitly formulated self-evaluations of possessions is atready on the borderline of being judged as a socially negative self-presentation technique

Thus, SW's and SM's acceptance of M's evaluation does not appear very spontaneous or enthusiastic. However. one should not draw the false conclusions from the lack of such self-evaluation processes in other conversations that in such cases no self-presentation techniques have been used, the techniques which have been used are frequently only more refined and thus less noticeable than those used by $M$.

In what follows SM asks the question whether $\mathrm{M}$ has ever exhibited the works of other artists in his gallery. $M$ explains that he does not do this for legal reasons and at the most he could have one guest exhibitor

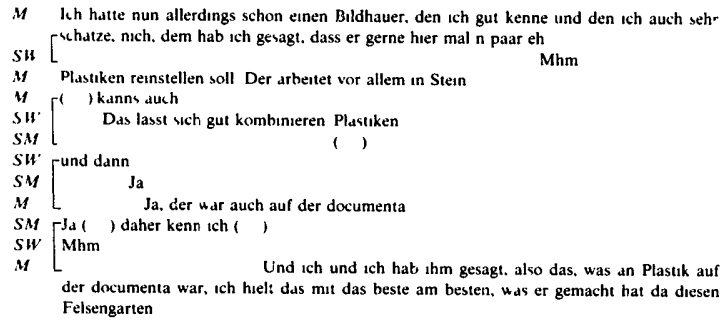

[M I did have a sculptor once who I know very uell and who I very much admire, you see, and I SH. [sald to him that l'd be pleased to have here a couple uh of sculptures displayed He works $M$ mainly in stone ( And is good at $t$, too

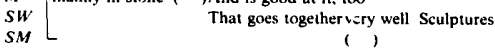




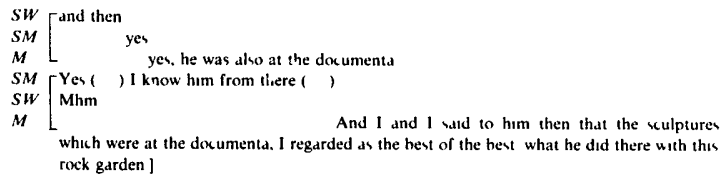

$M$ also uses this passage for indirect self-presentation First he takes It upon himself only as a duty to answer the opening question of SM concerning the exhsbition of work by other artists And even the mentioning of his acquaintance with the sculptor and his formulation of his evaluation for him serves mainly to explain why $M$ offered to exhibit the scuiptor in the first place. By means of the following comment that the sculptor has also exhibited at the documenta (which especially in Germany is very well-known) M's offer ard his positive relationship io the sculptor achieve a retrospective new importance: through the participation in the documenta and the thus expressed fame of the sculptor, $M$ himself experiences an increase in value as a person and as a sculptor. M supports this increased evaluation by saying that he elevated his acquaintance above the mass of documenta artists. thus demonstrating at the same time through his prasse his own competence as a judge of art. The self-presentation technique used here by $M$ is more difficult to see through in the real communication act. In order to prevent misunderstanding I must mention here that in using the expression 'self-presentation technique' I am not presupposing a conscious strategy in behavior; rather we must assume that self-presentation techniques learned in the course of socialization are. like much other routıne behavior, quasi-automatı ally used in communication and that they are partially removed from conscious control

A special refinement in the reference of $M$ to the documenta consists of the fact that, on one hand, it serves the positive evaluation of the sculpter and indirectly of $\mathrm{M}$, and that on the other hand he uses the documenta as a negative example in order to define his own artistic position. (We will return later to another figure showing a simılar contradictoriness even more clearly.)

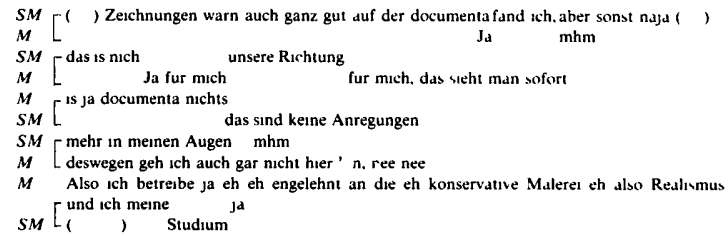




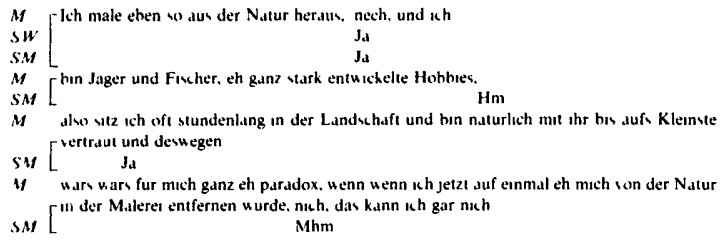

[St, I thought the drawings at the documenta were also quite good

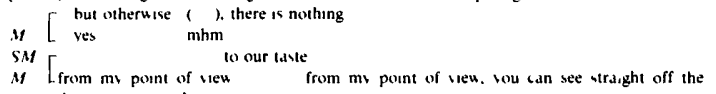

$M$ is a landscape painter of the rather traditional type which has received a mixed response. Thus for $M$ there is probably farrly intense pressure to justify himself with respect to his style of painting For the purpose of stabilizing one's own socially threatened position and for protecting oneself from the attack of others there are certain soctaily stereotyped procedures. For example. one can try to devalue other positions; $\mathbf{M}$ chooses this frocedure by cutting himself off from the artistic styles that one associates with the documenta. In addition there is the technique of defining his position by means of a flattering characterization: $M$ uses this technique when he describes his style of paintıng with the categories "conservative painting" and "realısm"; at least with the latter category the questıonable features of his paintıng style are neutralızed or 
'defined away' Finally, $M$ relies on the procedure of construing his position as a matter of necessity: the root of his painting is in his two hobbies hunting and fishing and so for him paintıng is not separable from nature. The necessity of a position always presupposes the competence to fill this position, $M$ provides proof of this competence by defining himself as being maxımally familar with the countryside.

SM grasps M's definition of his position and describes the relationship to nature as something in common between them (including SW) This is also supported by $\mathbf{M}$. but he immediately separates himself from the paintıng style of SW who studies at an art academy and in whom he stıll thinks he sees noch sehr starke Impulse aus Ihrem eigenen Unterricht ['a strong influence from her teachers'].

As support for his evaluation, which SW admits, $M$ adds the following

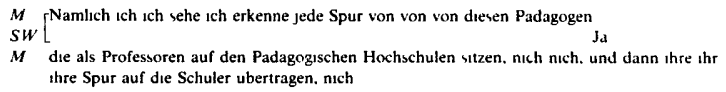

I $M$ [Namely, I I see. I recognize every trace of of these paedogogues, who are actung as $S M[$ yes

$M$ professors in the Teachers ${ }^{*}$ Training College. no, no, and then they transmit thesr characterisics to their pupils, right ]

This passage has two functions in M's self-definition First it becomes clear from the judgmental way that $M$ speaks about the art professors (one might add. "these so-called paedagogues who transmit their paintıng-style like an infectious disease to their pupil"), that $M$ has serious reservations about the academ.c practice of art. These reservations result again from the procedure of undervaluing other positions in order to secure one's own: $M$ is self-taught and therefore has $t$ i rotect himself against the possible criticism that he has not mastered $\mathrm{F}$. . ig technique because he lacks formal training. The prerequisıtes for definıng himself as a competent painter are improved. If $\mathbf{M}$ challenges the dependence of competence on academic training. Secondly, a central socially stereotyped defining characteristic of an artistic personality is its genuineness or uniqueness.. When $M$ denies this characteristic to the student SW, he indirectly claims it for himself; this is again a typical procedure in self-definition or self-presentation, particularly when it is used in the framework of disassociatıng oneself from something.

The characteristic of uniqueness is also explicitly taken up as the conversation continues $\mathrm{SM}$ asks $\mathrm{M}$ to what extent he is influenced by other artists and in response $M$ disclaims any direct influence from teachers

\footnotetext{
$M \quad$ Ich hab das Gluck gehabt, dass ıch immer ne Lehrer gehabt habe. aber auch Professoren, eh die also ein Lehramt hatten. ja und die ham. eh ich war $S W$ 
1 hefreundet mit ihnen, und die ham stch anmer $w$ fur das interessert. was ich machte und weil die wussten, ich war son richtiges Wildgemuse, nich, al wi das unheenflussbar thlich nich, und th die ham mir. Juch Mohn sigte.

$S, I$ ihm

M fen Gluck, daw Sie nicht zur Akademie gegangen snd. nich, wgte er SMl Mhm

I I had the good lack that I alwat had teachers, hut aloo professors wh they also has teaching $s M\left[\begin{array}{c}\text { porstlions, and thev had. } \\ \text { yes } \\ \text { ves }\end{array}\right.$

$M$ and I was friends with them and thev were als ays interested in what I was doing. because fher, knew I was a kind of rea! wild flower, in other words that I remaned uninfluenced and S.M [I mhm

If ther sald to me. also Mohn sad. that it was luchs. I never went to an adeadems. that's what he $S M L$ mhm

11 and |

This passage is the culmination of the direct self-presentation of $M$ His unicueness as an artist is presented in the image of the wild flower that reaches It) full beauty in free nature without the efforts of a gardener $M$ defines himself as a natural talent who would only have been spoilt by an academsc trainıng. M secures this self-definition (by a standard procedure) by citing authorities. on one hand he refers to a group of unspecified size (and thus indirectly implies a large zroup) of professors friendly to him. on the other hand he cites the artist Mohn who enjoys a great reputation in the circle of artistic acquantances that $M$. SW and SM have in common. Here we immediately notice again the phenomenon of contradictory evaluation of social authorities: in the previous passage $\mathbf{M}$ completely devalued the group of art professors in their role as pedagogues, now he decorates himself with a positive self-evaluation which he claims they have given (if professors were friendly with him and were interested in his painings. then they could not have regarded his pictures as being bad).

The analysis of self-definition of an artist and his self-presentation technıques presented here as an example would have to be carried out in a similar fashion for all the roles involved in participation in art I cannot carry out this task here, but the reader should be able to extrapolate the manner in which the same or sımılar technıques would be applied in thi case of other roles. Special research interest should be devoted to the recipient of art. In miy opınıon, there are numerous stereotypical self-definitions which can be interpreted from the manner in which one participates in art or communicates about art (for example, the deep thinker, the inituate, the expert, the open-minded one, the enthustast etc.). However, at must not be forgotten that participation in art and communication about art do not serve only the purpose of self-definition and its accompanying interactions; rather it is much more concerned with shaping 
a reality that is suited to this self-definition. Looking more closely, this comment suggests a new connection with the discussion of fictionality in this volume participation in art and communication about art make possible the creation of a reality which may not correspond exactly to other areas of social reality. We are speakıng now, not about fictionality which is related exclusively to that presented in a uurk of art. but rather more generally about the phenomenon of producing a reality which takes place in many social contexis (for example in conflicts) and which is not linited to the field of art.

The elaboration of the fictionality concept as presented here in connection with the productive activities of participants in art opens the way, it seems to me, for a critical analysis of certain unpleasant by-products of the art industry. I will mention a few, examples which are in ro way new.

- the teacher who projects his own latent delusions of genius on to a pupil and pushes him into an unfortunate artıstic career.

- the unsuccessful author who styles himself as an unrecognized genius (cf the controversy between Narwal 1981 and Wajenba.h 1981).

- the moderator of a cultural program who expluits his guests as "sparring partners' for his own self-presentation

On the basis of the results of a closer inalysis of such extreme examples, 1 would hope that in the long run it would be possible to achieve a greater social consciousness for much of the now still latent mechanısms of participation in art or those which have been immunized $b$ mystification and in this way come to a more realistic evaluation of the potentials and functions of art

\section{References}

Greiner. K 1981 Aussenseiter sind eher Legende Wochenzeitung DIE ZEIT 49 (2711 81) 47-48

Heine, $\mathrm{V}$ and $\mathrm{H}$ Wesemuller 1978 Deutungs- und Typisterungsmuster ausgewahlter visteller Objekte und der Bezug zu Bıographie und Lebenswelt ıhrer Betrachter Diplomarbeit Iniversity of Bielefeld

Hurrelmann. B 1981 Kindeihteratur im sozialen Kontext Ms University of Essen

Kallmeyer, W 1977 Verstandigungsprobleme in Altagsgesprachen Der Deutschunternch 29(6) $52-69$

Kallmeyer. W 1979 '(Expressif) eh bien dis donc, hein' pas hien - Zur Beschreibung von Exaltation als Interaktionsmodalitat' In $R$ Kloepler et al. eds. Bildung und Ausbilding in der Romanu, Vol I Munchen Fink

Kallmever. $W$ and $W$ Kindt 1979 'Die empirische Untersuchung von Versiehenproblemen' In Zuischenstation Universitat Bielefeld Bielefeld Kommissionsverlag Pfeffer

Kındt, W 1980 'Komplexıtat und Verstandlıchkeıt von Texten' In D Hintzenberg et al, 1981 Zum Literaturbegriff in der Bundesrepublik Deutschland Braunschweig Vıeueg pp 217-238

Kindt. W 1981 Some foundational and methodical problems of the empirical theory of literature Poetics 10 483-513 
Kindt, W and S J Schmidt. 1979 'Motivationen und Aspekte einer empirischen Literaturwissenschaft' In SJ Schmidt. ed

Narwal. P 1981 Hilferuf an langst Verstorbene Zeitung Frankfurter Rundschau 190 (198 81 ) 7

Richter-Reichenbach, K-S 1977 Grundlagen einer museum-didaktıschen Konzef.ion zur Vermittlung zeitgenossischer Kunst an Jugendlıche und Erwachsene Dusseldorf

Schmidt, S J ed 1979 Empirie in Literatur- und Kunstwissenschaft Munchen Fink

Sthmidt. SJ 1980 Grundriss der empirsschen Literaturwissenschaft. Vol 1 Braunschweig Vieweg

Wagenbach, K 1981 'Folgen des Gentekults' In Frankfurter Rundschau, 201 (29.81) 12

Walther Kindt took degrees in mathematics and logies He is teaching linguisics at Bielefeld University and carrving out research projects in formal grammar, empirical semanties and conversational analysis He has published articles concerning these subjects and topics in the horderline of linguistics and the theory of litelature in various books and journals 